\title{
Industry backs 'downsizing' public research, but not joint projects
}

Washington. Industrial research directors in the United States are backing cuts in government research and development budgets being proposed by the Republicandominated Congress as giving universities and federal laboratories a much-needed impetus to improve their performance.

At the same time, however, they fear that the closure of technology support programmes will severely inhibit US industry's ability and willingness to carry out high-risk research and development (R\&D).

This double message has come from a forum of 60 research bosses from companies Motors, organized by the Industrial Research Institute (IRI) and held in Washington late last month to discuss the impact of Congress's budget plans.

According to a summary of the meeting prepared by Chuck Larson, executive director of IRI, the proposed cuts are "a healthy provocation for self-examination and improvement by the federal labs and universities". $\mathrm{He}$ points out that industry has itself been 'downsizing' for the past ten years, echoing the response of many industrial research managers to the cuts now facing the publicly-funded research infrastructure. "A little squeezing sometimes helps all of us," says David Knowlen, director of technical affairs at Boeing and co-chair of the forum.

But the forum expressed deep misgivings about Congress's plans to cut back on technology programmes which directly support industrial R\&D. These proposals could "turn the clock back 10 or 15 years," the forum summary said - a reference to concern that US government policy would return to its position before a desire actively to encourage technology transfer was first enshrined in legislation in the late 1970s. such as $3 \mathrm{M}$, DuPont, Mobil and General

Two threatened programmes alone the commerce department's Advanced Technology Program (ATP) and the defence department's Technology Reinvestment Program (TRP) - are now matched by private sector commitments totalling $\$ 5$ billion over five years. This is little compared to US industry's total annual R\&D expenditure of around $\$ 100$ billion. But Larson says that the two programmes may represent up to

\section{IMAGE UNAVAILABLE FOR COPYRIGHT REASONS}

Plugging in? Supporters of the electric car say that federal funds provide fuel for high-risk ventures.

half industry's spending on high-risk $R \& D$, and have created "a 50-100 per cent increase" in what would otherwise be done in this field.

"High-risk R\&D is very hard to sell to any board of directors," says Knowlen. "Much of it is supported by partnerships between government and industry." Since the end of the cold war, the Boeing director adds, the amount of research supported for military purposes "has greatly narrowed".

Both ATP and TRP have been targeted for elimination by the House of Representatives. The Clinton administration, however, has promised to defend the programmes, and the Senate is likely to try to preserve at least part of TRP.

\section{Gupta associates feel the reflected heat}

New Delhi. The Panjab University in Chandigarh has set up a committee of four faculty members to decide whether, and if so how, to punish two research associates of the geologist Viswa Jit Gupta, who was found guilty last year of faking geological data (see Nature 371,368 ; 1994).

One of the scientists, Arun Ahluwalia, claims that any such punishment would be unjustified. He points out that a commission of inquiry set up to review Gupta's work established that he and his colleague were victims of Gupta's deception, and alleges that they are now being victimized by the university.

But the university's vice-chancellor, $\mathbf{T}$. $\mathbf{N}$.
Kapur, says that although the commission showed the two researchers to be innocent, consideration now needs to be given to withdrawing any benefits that they may have received as a result of their association with Gupta - as the commission had requested.

The Society for Scientific Values, a group of Indian scientists committed to upholding good scientific conduct, is to consider Panjab University's actions at its October meeting. Meanwhile, according to Avtar Singh Paintel, a former president of the group, the society is writing to the university asking it to stop "harassing" the two researchers.

K. S. Jayaraman
Republicans on Capitol Hill claim that industry has done little to defend these programmes, preferring to use its formidable lobbying power to push for deregulation or tax breaks, making it easier to raise capital.

But Knowlen replies that the aerospace industry, at least, has made its position quite clear. The chief executive officers of the seven largest companies wrote to Congressional leaders in May, warning that ending

$\vec{a}$ the technology programmes would damage US competitiveness.

The IRI forum revealed some divisions between participants. Jean Bonney, for example, director of external research at DEC and the forum's other co-chair, threw some doubt on the general effectiveness of the ATP and TRP by comparing them to the European Union's much older and larger Framework research programme.

Bonney acknowledged that Framework has encouraged European companies to collaborate. But "if you look at exactly what [Europe] has got, in technology and product terms, we haven't seen a whole lot," she said.

The research directors expressed concern that the US government appears to have been backing away from Co-operative Research and Development Agreements (CRADAs) in the past few months - a trend sensed, for example, by the largest single CRADA participant, General Motors.

The directors also said industry would boost support for university research if the government cuts it, but not by enough to fill the hole this would leave.

Industry could live with reduced graduate output from the universities, they said, given the current record level of supply. Its ability to innovate would be hit by cuts in engineering research, they said, but not in some scientific disciplines - although they were not specific on what these might be.

The forum did not favour the restoration of the Research Tax Credit, a claimed incentive for companies to boost their reported research spending each year that has long been pursued by corporate lobbyists in Washington. It branded the tax credit as "more of a financial tool than a technology tool for most companies".

The House and Senate budget proposals will be reconciled this month, and the fate of the technology programmes sealed in October, when they collide with the Clinton administration's own priorities in a festival of brinkmanship, known as the 'train-wreck', from which final budget numbers will emerge.

Colin Macilwain 